\title{
ANALISA PETA DESA SKALA 1:5000 BERDASARKAN PERATURAN KEPALA BIG NOMOR 3 TAHUN 2016 (Studi Kasus: Desa Beran Kabupaten Ngawi)
}

\author{
Agung Budi Cahyono, Nizar Zulkarnain \\ Departemen Teknik Geomatika FTSLK-ITS, Kampus ITS Sukolilo, Surabaya, 60111 \\ Email: agungbc@geodesy.its.ac.id
}

\begin{abstract}
Abstrak
Dalam rangka mewujudkan amanat nawacita dibutuhkan Peta Desa sebagai rujukan bagi Kementrian/Lembaga serta Pemerintah Daerah dalam program pembangunan. Peta desa adalah peta tematik bersifat dasar yang berisi unsur dan informasi batas wilayah, infrastruktur transportasi, toponim, perairan, sarana prasarana, penutup lahan dan penggunaan lahan yang disajikan dalam peta citra, peta sarana dan prasarana, serta peta penutup lahan dan penggunaan lahan. Hal tersebut sesuai dengan UU Nomor 6 Tahun 2016 tentang Desa, yang menjelaskan bahwa Desa merupakan subjek dari pembangunan. Peraturan Kepala BIG Nomor 3 Tahun 2016 tentang Spesifikasi Teknis Penyajian Peta Desa merupakan peraturan yang diterbitkan oleh Badan Informasi Geospasial untuk mengatur pembuatan sebuah Peta Desa. Dengan terbitnya aturan tersebut maka dilakukan analisa terhadap Peta Desa Beran yang digunakan sebagai media peningkatan status dari desa menjadi kelurahan. Analisa dilakukan terhadap ukuran muka peta, interval grid peta, spesifikasi tata letak, pewarnaan simbol peta, spesifikasi penulisan informasi peta, dan keefektifan simbol yang digunakan pada Peta Desa Beran, Kabupaten Ngawi. Hasil penelitian ini menunjukkan nilai ukuran muka peta dan susunan/spesifikasi tata letak informasi peta desa yang digunakan oleh Peta Desa Beran masih belum sesuai dengan Peraturan Kepala BIG Nomor 3 Tahun 2016 tentang Spesifikasi Teknis Penyajian Peta Desa. Terdapat pula tiga objek di lapangan yang simbolnya tidak diatur dalam Peraturan Kepala BIG Nomor 3 Tahun 2016 tentang Spesifikasi Teknis Penyajian Peta Desa, yaitu Yayasan, Panti, dan Koperasi Simpan Pinjam (KSP). Selain itu simbol yang ditampilkan pada Peta Desa Beran sebagai pengganti objek yang ada di lapangan terlalu banyak, dikarenakan tidak semua objek pada simbol tersebut dimiliki oleh Desa Beran.
\end{abstract}

Kata Kunci: Analisa Kartografi, Peraturan Penyajian Peta Desa, Peta Desa.

\section{PENDAHULUAN}

Kartografi adalah studi dan praktik membuat peta atau globe. Artinya kartografi selalu berhubungan serta membahas secara khusus tentang pembuatan peta serta interpretasinya. Peta secara tradisional sudah dibuat menggunakan pena dan kertas, tetapi munculnya dan penyebaran komputer sudah merevolusionerkan kartografi. Peta desa tentu sama dengan peta lainnya, yaitu menggunakan bantuan simbol kartografi untuk mewakili objek atau potensi yang dimiliki oleh desa tersebut. Namun, pembuat peta desa yang berbeda - beda juga terkadang menggunakan simbol kartografi yang berbeda pula. Maka menurut Peraturan Kepala Badan Informasi Geospasial Nomor 3 Tahun 2016 mengenai Spesifikasi Teknis Penyajian Peta Desa, terkait dengan peraturan pemerintah tentang perlunya pembuatan peta desa yang akurat, terintegrasi, dapat dipertanggungjawabkan, dan memiliki standar kartografi yang sama antar peta desa, maka perlu adanya Spesifikasi Teknis Penyajian Peta Desa yang mengatur tentang penggunaan simbol kartografi sehingga penggunaan simbol bisa seragam dan sama persis walaupun pembuat petanya berbeda, serta dapat dijadikan acuan bagi para pemangku kepentingan. Dalam penelitian ini akan menganalisis kartografi dalam pembuatan Peta Desa Beran yang mengacu pada Peraturan Kepala BIG Nomor 3 Tahun 2016 mengenai Spesifikasi Teknis Penyajian Peta Desa. Adapun analisa yang dilakukan berdasarkan aturan mengenai skala dan ukuran peta, penyajian peta citra, simbol, tata letak dan spesifikasi tata letak peta, dan spesifikasi penulisan info peta.

\section{METODOLOGI PENELITIAN}

Lokasi penelitian ini dilakukan di Desa Beran Kabupaten Ngawi, Jawa Timur 

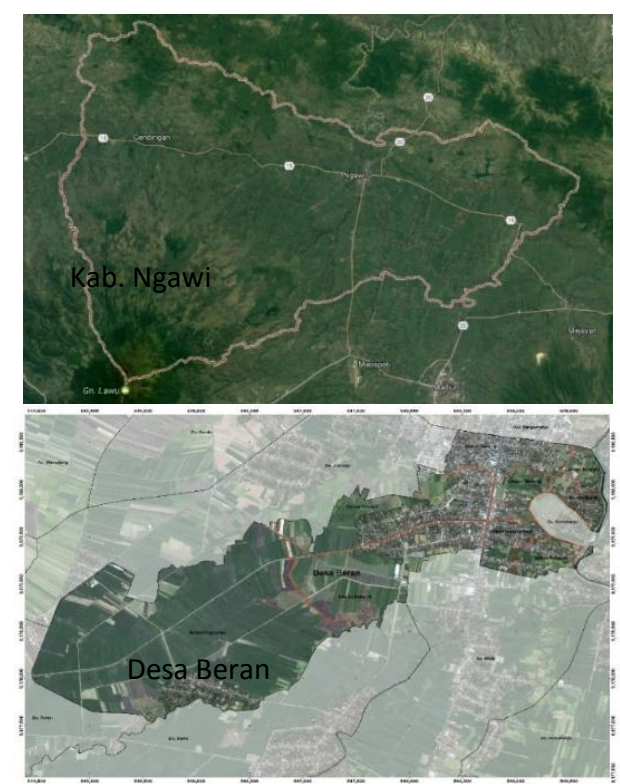

Gambar 1. Lokasi Penelitian (Citra Kabupaten Ngawi, Badan Informasi Geospasial 2016)

Dalam penelitian ini data yang digunakan adalah Peta Desa Beran tahun 2016 dan Peraturan Kepala BIG Nomor 3 Tahun 2016 tentang Spesifikasi Teknis Peta Desa.Adapun peralatan yang digunakan adalah laptop Asus X450J untuk pengolahan data, analisa data, dan pembuatan laporan. Serta aplikasi Sistem operasi Windows 10 Professional 64-bit dan ArcGIS 10.3 untuk mengolah data peta dan analisa kartografi.

\section{ANALISA}

Analisa terhadap ukuran muka peta dan ukuran informasi peta pada peta desa.

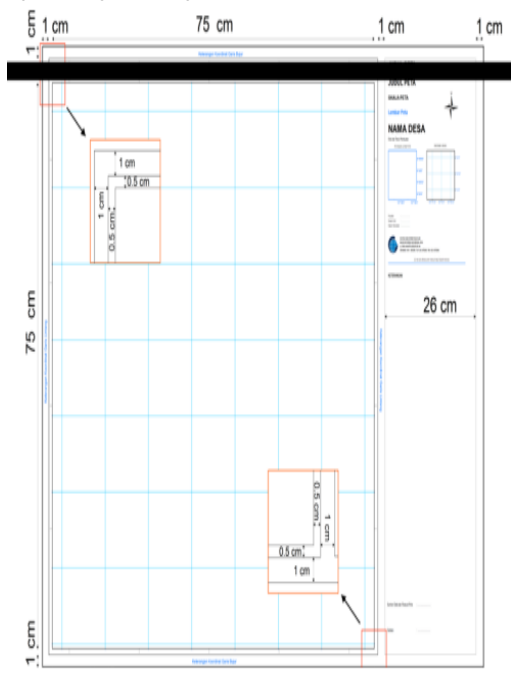

Gambar 2 Aturan mengenai Ukuran Muka Peta dan Informasi Peta pada Sebuah Peta Desa

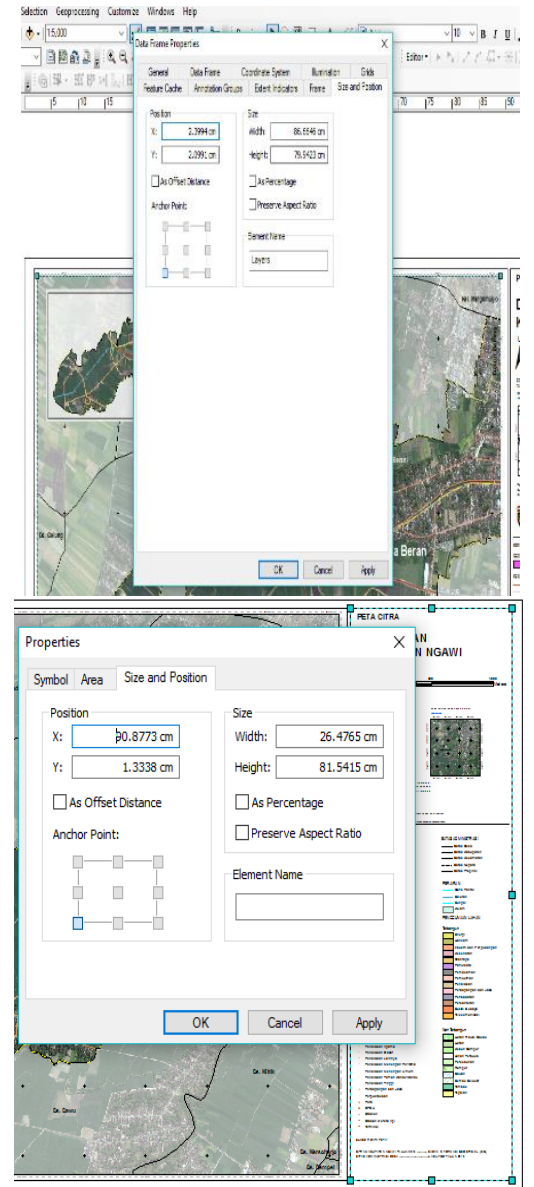

Gambar 3 Hasil Ukuran Muka Peta dan Informasi Peta pada Peta Desa Beran

Berdasarkan hasil tersebut, maka diperoleh Analisa bahwa ukuran muka peta pada Peta Desa Beran tidak sesuai dengan aturan, sedangkan ukuran informasi peta pada Peta Desa Beran sudah sesuai dengan aturan yang ada.

a. Analisa interval grid pada peta desa

\begin{tabular}{|c|c|c|c|c|c|}
\hline \multirow[b]{2}{*}{ No } & \multirow{2}{*}{ Skala } & \multicolumn{2}{|c|}{ Kertas A0 } & \multicolumn{2}{|c|}{ Kertas A1 } \\
\hline & & Interval Grid & Gratikul & Interval Grid & Gratikul \\
\hline 1 & $1: 2.500$ & $\begin{array}{c}250 \mathrm{~m}, \\
\text { penulisan } \\
\text { angka tiap } \\
500 \mathrm{~m}\end{array}$ & 5" (detik) & $\begin{array}{c}250 \mathrm{~m}, \\
\text { penulisan } \\
\text { angka tiap } 500 \\
\mathrm{~m}\end{array}$ & 5" (detik) \\
\hline 2 & $1: 5.000$ & $\begin{array}{c}500 \mathrm{~m}, \\
\text { penulisan } \\
\text { angka tiap } \\
500 \mathrm{~m}\end{array}$ & $10 "$ (detik) & $\begin{array}{c}500 \mathrm{~m}, \\
\text { penulisan } \\
\text { angka tiap } 500 \\
\mathrm{~m}\end{array}$ & 10" (detik) \\
\hline 3 & 1:10.000 & $\begin{array}{c}1000 \mathrm{~m}, \\
\text { penulisan } \\
\text { angka tiap } \\
1000 \mathrm{~m}\end{array}$ & $20 "$ (detik) & $\begin{array}{c}1000 \mathrm{~m}, \\
\text { penulisan } \\
\text { angka tiap } \\
1000 \mathrm{~m}\end{array}$ & 20" (detik) \\
\hline 4 & $\begin{array}{c}\text { 1:10.000 } \\
\text { indeks }\end{array}$ & $\begin{array}{c}1000 \mathrm{~m}, \\
\text { penulisan } \\
\text { angka tiap } \\
1000 \mathrm{~m}\end{array}$ & 20" (detik) & $\begin{array}{c}1000 \mathrm{~m}, \\
\text { penulisan } \\
\text { angka tiap } \\
1000 \mathrm{~m}\end{array}$ & $20 "$ (detik) \\
\hline
\end{tabular}

Gambar 4 Aturan mengenai Ketentuan Interval Grid pada Sebuah Peta Desa 


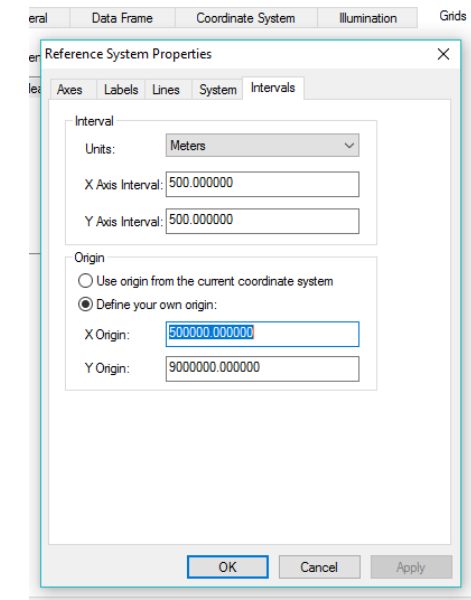

Gambar 5 Hasil Interval Grid pada Peta Desa Beran

Berdasarkan hasil tersebut, maka diperoleh Analisa bahwa interval grid yang digunakan pada Peta Desa Beran sudah sesuai dengan aturan yang ada.

b. Analisa susunan/spesifikasi tata letak informasi peta pada peta desa

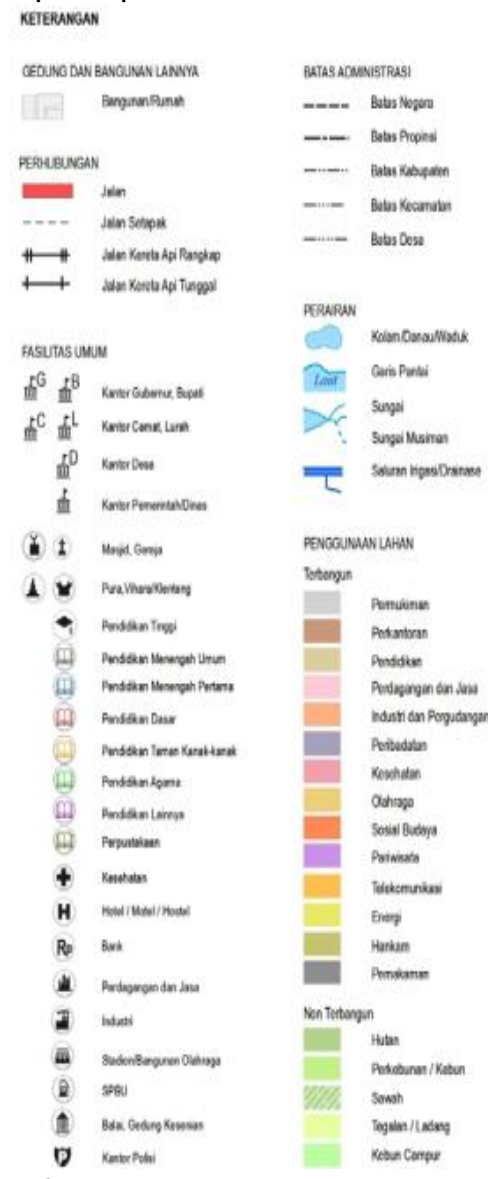

Gambar 6 Aturan mengenai Susunan/Spesifikasi Tata Letak Informasi Peta pada Sebuah Peta Desa

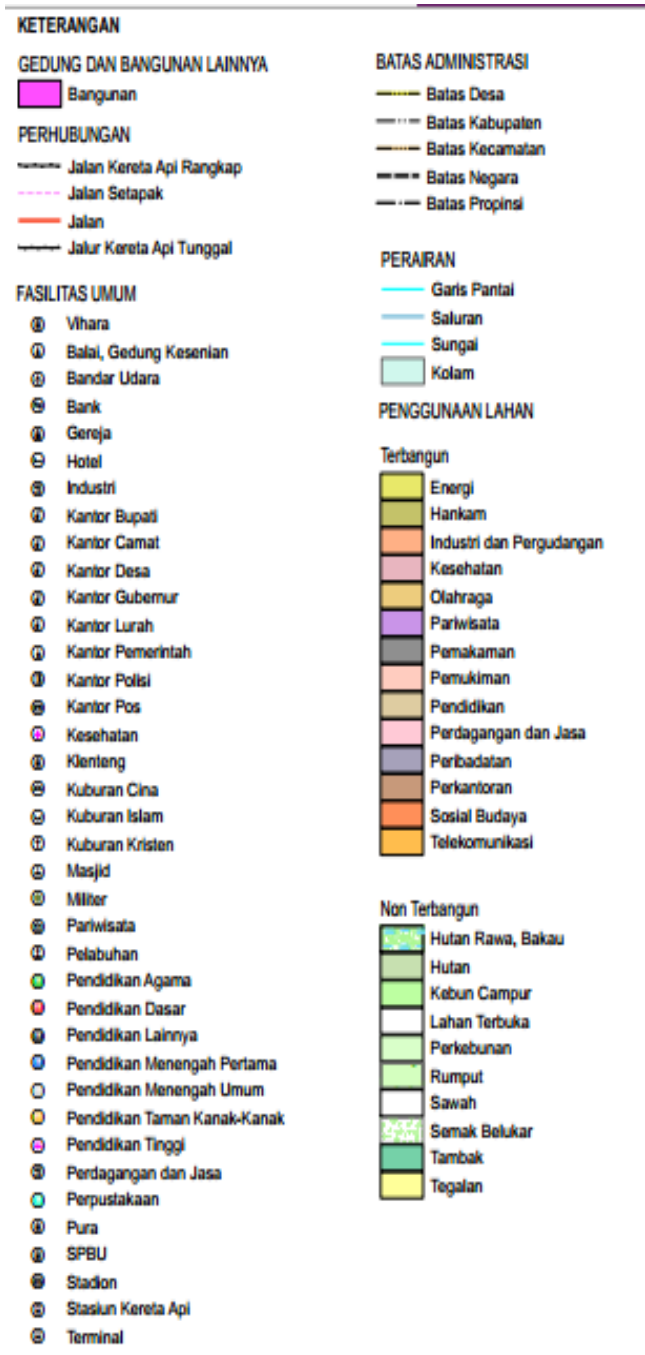

Gambar 7 Hasil Susunan/Spesifikasi Tata Letak Informasi Peta pada Peta Desa Beran

Berdasarkan hasil tersebut, maka diperoleh analisa bahwa susunan/ spesifikasi tata letak informasi peta desa pada Peta Desa Beran tidak sesuai dengan aturan yang ada.

c. Analisa aturan pewarnaan simbol peta desa

\begin{tabular}{|c|l|c|c|c|c|c|}
\hline 3.6 & $\begin{array}{l}\text { Pendidikan } \\
\text { Agama }\end{array}$ & $\begin{array}{l}\text { Titik } \\
\text { Teperti Pondok }\end{array}$ & \multicolumn{2}{|c|}{$\begin{array}{l}\text { Sesantren, Taman } \\
\text { Pendidican auran, dan } \\
\text { lainnya yang sesuai }\end{array}$} & \multicolumn{2}{|c|}{} \\
\hline \hline Hijau & 100 & 22 & 100 & 00 \\
\hline Putih & 00 & 00 & 00 & 00 \\
\hline $\begin{array}{c}\text { Mask: } \\
\text { Hitam }\end{array}$ & 00 & 00 & 00 & 100 \\
\hline
\end{tabular}

Gambar 3.7 Aturan mengenai Salah Satu Ketentuan Pewarnaan Simbol pada Sebuah Peta Desa 


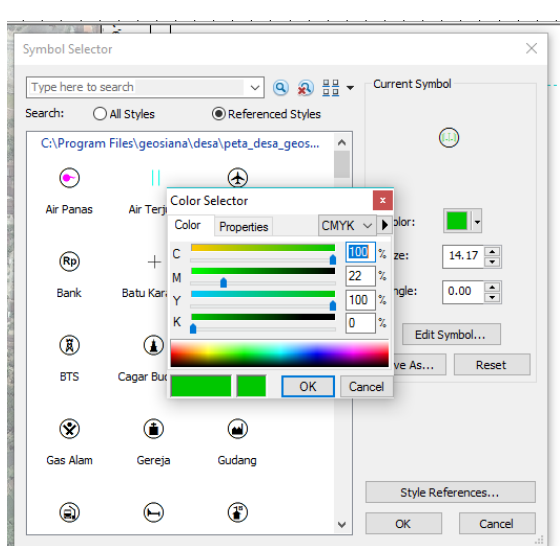

Gambar 8 Hasil Pewarnaan Salah Satu Simbol pada Peta Desa Beran

Berdasarkan hasil tersebut, maka diperoleh Analisa bahwa pewarnaan simbol yang digunakan pada Peta Desa Beran sudah sesuai dengan aturan yang ada.

d. Analisa spesifikasi penulisan informasi pada peta desa

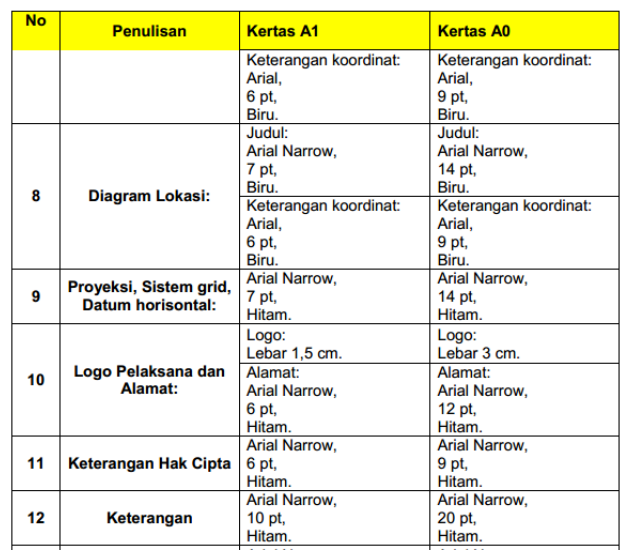

Gambar 9 Aturan mengenai Spesifikasi Penulisan Informasi pada Sebuah Peta Desa

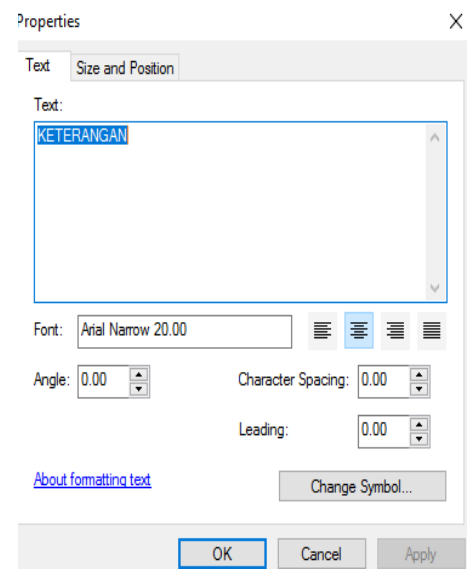

Gambar 10 Hasil Spesifikasi Penulisan Informasi pada Peta Desa Beran

Berdasarkan hasil tersebut, maka diperoleh Analisa bahwa spesifikasi penulisan informasi peta desa yang digunakan pada Peta Desa Beran sudah sesuai dengan aturan yang ada.

e. Analisa mengenai aturan digitasi objek yang ada di lapangan dalam pembuatan peta desa

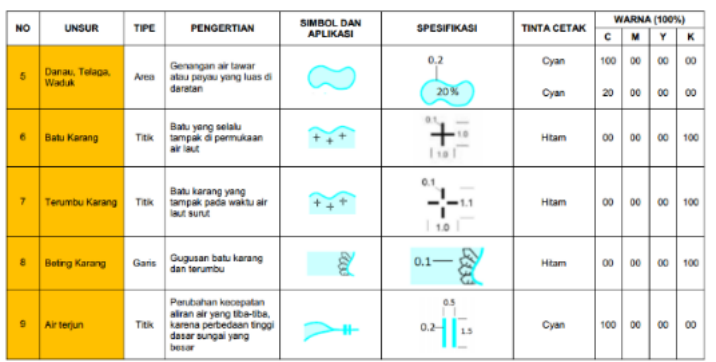

Gambar 3.11 Aturan mengenai Spesifikasi

Ketebalan Outline pada Hasil Digitasi Objek yang Ada di Lapangan pada Sebuah Peta Desa

Berdasarkan hasil tersebut, maka diperoleh Analisa bahwa pada aturan yang ada, yaitu Peraturan Kepala BIG Nomor 3 Tahun 2016 tentang Spesifikasi Teknis Penyajian Peta Desa tidak disebutkan aturan mengenai tata cara digitasi yang benar, hanya aturan mengenai ketebalan outline dari hasil digitasi tersebut, sehingga hasil digitasi pada Peta Desa lain bisa saja berbeda - beda meskipun telah mengacu pada PerKaBIG Nomor 3 Tahun 2016 tersebut.

\section{KESIMPULAN}

Berdasarkan Peta Desa Beran yang dibuat oleh Pemerintah Kabupaten Ngawi, hanya ukuran muka peta dan susunan/spesifikasi tata letak informasi peta desa belum memenuhi aturan. Untuk ukuran informasi peta, penggunaan interval grid, pewarnaan simbol yang digunakan, dan spesifikasi penulisan informasi peta desa sudah sesuai dengan Peraturan Kepala BIG Nomor 3 Tahun 2016 tentang Spesifikasi Teknis Penyajian Peta Desa. Maka dengan terdapat 6 (enam) parameter, dengan 4 (empat) parameter sesuai dan 2 (dua) parameter tidak sesuai, dapat diketahui bahwa tingkat kesesuaian Peta Desa 
Beran yang dibuat oleh Pemerintah Kabupaten Ngawi dengan Peraturan Kepala BIG Nomor 3 Tahun 2016 adalah 66,67\% dengan nilai maksimal $100 \%$. Selain itu, pada Peta Desa Beran Kabupaten Ngawi, semua simbol yang disebutkan dalam aturan digunakan oleh pembuat peta tersebut meskipun objek yang disimbolkan tidak ada pada Desa Beran. Kemudian masih terdapat beberapa objek di Desa Beran yang belum diatur simbolnya pada Peraturan Kepala BIG Nomor 3 Tahun 2016, yaitu Yayasan, Panti, dan Koperasi Simpan Pinjam (KSP).

\section{DAFTAR PUSTAKA}

Eckerstorfer, M. 2015. Cartographic Analysis of Avalanche Hazard Maps. Vienna, Austria: Department of Geography and Regional Planning, University of Vienna.

Halik, L. 2012. The Analysis of Visual Variables for Use in the Cartographic Design of Point Simbols for Mobile Augmented Reality Applications. Poznan, Poland: Department of Cartographic and Geomatics, Adam Mickiewicz University Poznan.

Jiang, B. 1996. Cartographic Visualization: Analytical and Communication Tools. Berlin, Germany: Institute of Geographic Sciences.

Kertanegara, U., Nugraha, A.L., dan Sudarsono, B. 2013. Peninjauan Secara Kartografis Dalam Pembuatan Peta Kampus Universitas Diponegoro. Semarang.

Peraturan Kepala BIG Nomor 3 Tahun 2016. 2016. Spesifikasi Teknis Penyajian Peta Desa. Badan Infomasi Geospasial (BIG).

Robinson, A.H. 1967. Psychological Aspect of Color in Cartography. International Yearbook of Cartography. Chapter 7:50-59.

Robinson, A.H. 1995. Elements of Cartography, $6^{\text {th }}$ Edition. New York: John Wiley \& Sons

Undang - Undang Republik Indonesia Nomor 6 Tahun 2014. 2014. Desa. Pemerintah Republik Indonesia. 